\section{Ways to surmount the language barrier}

Sir - Paul R. Sanberg (Nature 384, 608; 1996) has highlighted a further problem caused by the language barrier, when research published in a non-English language publication, for example Japanese, is missed by researchers who do not read the language and do not find the research listed and indexed in relevant databases. There are two possible solutions to this problem.

The first can be exemplified by the database Aquatic Sciences and Fisheries Abstracts, which is sponsored by four United Nations (UN) agencies (the Food and Agriculture Organization, the International Oceanographic Commission, the UN Environment Programme and the UN Division for Ocean Affairs and the Law of the Sea) and which receives input from three other international organizations, and from national partners in more than 20 countries. This large partnership base ensures a good coverage of the aquatic sciences literature, each partner covering the literature in its own language.

The second solution can be illustrated by the compilation CD-ROMs made available by the National Information Services Corporation, where many small databases, compiled for national and regional use, are brought together in one 'anthology' database, with duplicate references listed once only.

Both of these solutions can go some way towards making the work of those who publish in the less-accessible languages available to researchers worldwide.

\section{David S. Moulder}

National Marine Biological Library

Plymouth Marine Laboratory/

Marine Biological Association,

Plymouth PL1 2PB, UK

e-mail:d.moulder@pml.ac.uk

\section{NO prizes}

Sir - There is no doubt that the discovery of nitric oxide (NO) as an important biological mediator has had a major impact on many fields of scientific investigation, including study of the cardiovascular and pulmonary systems which is the focus of our practice and research.

The Lasker Prize in the United States was awarded last year to Robert Furchgott and Ferid Murad for work on nitrous oxides in the body. Although it could be argued that prizes are not important and that it is often difficult to make the right choice, we feel strongly that important omissions have been made in the awarding of the prize.

Although there had been some speculation linking endothelium-derived relaxing factor (EDRF) to nitrogencontaining compounds, the first paper based on solid experimental data and stating categorically that "EDRF is NO" (Nature 327, 524-526; 1987) was written by Salvador Moncada and colleagues, and was followed by many other seminal contributions from the same group including the discovery that "NO is synthesized from L-arginine" (Nature 333, 664-666; 1988). Papers of similar originality that have made an important contribution have been published by Lou Ignarro. These publications opened the floodgates for the current level of NO research and inspired many scientists and physicians, including us.

\section{Magdi Yacoub}

Julia M. Polak

Imperial College School of Medicine at the National Heart \& Lung Institute,

Dovehouse Street, London SW3 6LY, UK

\section{South Africa}

Sir - Nature and its South Africa correspondent, Michael Cherry, are to be congratulated on the Briefing on science in South Africa (384, 11-15; 1996). In many ways the country is unique; indeed, it can be described as two countries in one. In 1992 , the country's white community, considered alone, was placed 34 out of a total of 175 countries on the Human Development Index in terms of average life expectancy, educational attainment and basic purchasing power; black South Africans were placed at number 125 .

A striking aspect of the industrialized South Africa lies in the high level and quality of its scientific and technological capabilities. Your Briefing includes a reference to the way in which international links are helping to overcome years of isolation in science and other fields. But your coverage was restricted to assistance pertaining to bilateral cooperation, and made no mention of the role of multilateral organizations active in science.

Bilateral assistance is certainly important, but it is no substitute for the broadness of vision, ethical considerations and global concerns normally enshrined in multilateral cooperative schemes. It is for these reasons that UNESCO's programme for science is entitled "The sciences in the service of development". Even during the apartheid years, those involved in bilateral arrangements will have noticed the skewed manner in which science was promoted and practised in South Africa.

UNESCO is helping the South African government to carry out a comprehensive evaluation of academic development programmes in science and technology, with special reference to the historically disadvantaged institutions. This is expected to recommend how to remedy the unbalanced patterns of access to science, engineering and technology disciplines of disadvantaged students in the short and medium term.

South Africa is also increasing its international scientific links. It has, for example, recently joined the

Intergovernmental Hydrological programme, and is preparing to become a member of the Man and Biosphere programme. Membership of these programmes will allow it to tap into intellectual and financial resources for the conduct of scientific research and the exchange of information in key scientific areas related to water resources development, the protection of the environment and sustainable development. Luis B. Honwana

UNESCO, PO Box 11667, Tramshed, 0126 Pretoria, South Africa

\section{Ground rules}

Sir - Your News article about repairs to US radiotelescopes (Nature 384, 505; 1996 ) states that the Arecibo Observatory in Puerto Rico is built in the crater of an extinct volcano. In fact, the observatory is located in a sinkhole (a collapsed cave chamber). The Arecibo area has typical karst topography and is riddled with caves. The nearby Tres Pueblos sinkhole is the entrance to the Camuy Caves Park.

Eugenio L. de Hostos

Department of Biochemistry

and Cell Biology, MS140,

Rice University, Houston, Texas 77005-1892, USA

e-mail:hostos@bioc.rice.edu

\section{Stone Age confusion}

Sir - A recent News article (Nature 384, $605 ; 1996)$ referred to a taxonomical analysis that "proved that a popular television figure, Barney from the Flintstones, is not a dinosaur after all". Any child knows that Barney from the Flintstones is a Stone Age man, close friend of Fred Flintstone, and lives with dinosaurs despite all the fossil evidence to the contrary. However, Barney, who hosts a children's show on the US Public

Broadcasting System, is undoubtedly a dinosaur and pure gold to academics trying to accomplish anything at home while responsible for a toddler.

\section{A. John MacLennan}

Department of Neuroscience,

University of Florida,

Gainesville, Florida 32610, USA

e-mail:maclennan@icbr.ifas.ufl.edu 